\title{
Toxic Air Pollutants Notice of Construction for Rotary Mode Core Sampling Systems Three and Four and Modification of System Two
}




\section{RELEASE AUTHORIZATION}

Document Number: DOE/RI-94-117, Revision 1

Document Title: Rotary Mode Core Sampiing Systems Three and Four and Modification System Two

- This document, reviewed in accordance with DOE Order 1430.1D, "Scientific and Technical Information Management," and DOE G 1430.1D-1, "Guide to the Management of Scientific and Technical Information," does not contain classified or sensitive unclassified information and is:

\section{APPROVED FOR PUBLIC RELEASE}
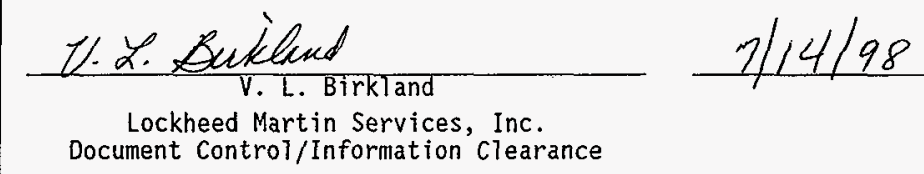

Document Control/Information Clearance

Revewad for Applied technology, 8uginess Sensitiv, Classified, Copyrightod, Export Controlled, Patent, Personal/Privato, Propniotary, Protectod CRADA, Trademark, Unclassified Controlled Nucleas Information.

Trademark Disclaimer. Referance herein to any specific commercial product, process, or service by trade name, trademark, manufacturer, or otherwise, does not necessarily constitute or imply its endorsement, recommendation, or favoring by the United Stater Government or any eqency thereof or its contractors or subcontractore. The viewe and opinions of authors expressed herein do not necessarily state of roflect those of the United States Government or any agency thereof. This report has been reproduced from the best available copy.

Printed in the United States of America.

Available to the U.S. Departmant of Enorgy and its contractere from the U.S. Dopartment of Enoroy Office of Sejentific and Technical Information, P.O. Box 62, Oak Ridgo. TN 37831; Telephone: 423/576-8401.

Availablo to the public from the U.S. Department of Commerce National Technical Information Service. 5285 Port Royal Roed, Springfield, VA 22161: Telephone: 703/487-4650. 


\section{REVISION HISTORY} margin.

All changes made in this document are noted by a vertical bar in the left

The Washington State Department of Ecology approved the original Notice of Construction for the Rotary Mode Core Sampling System Two in 1993 (DOE/RL-93-41). A State Environmental Policy Act (SEPA) Environmental checklist was completed and submitted during the 1993 approval process.

Revision 0 was submitted to Ecology in 1995 and replaced the original 1993 NOC.

Revision 1 updates Revision 0 as follows.

- The waste tank vapor characterization program is nearing completion. All existing vapor space data will be used when calculating toxic air emissions from Rotary Mode Core Sampling activities. The vapor space data from 102 waste tanks can be found in the Tank Waste Inventory System available on the World Wide Web located at URL http://TWINS.PNL.GOV:8001/.

- Revision 0 did not provide a method to perform emissions calculations for compounds that do not have a small quantity emission rate listed in Washington Administrative Code Chapters 173-460. A method to estimate emissions for these chemicals consistent with the technical approach in Revision 0 is included in Revision 1, Section 6.0.

- The Appendix B emissions calculation formula were modified. Revision 1 calculates emissions per tank. Revision 0 calculated annual emissions per exhauster 
DOE/RL-94-117, Rev. 1

$07 / 98$

This page intentionally left blank. 


\section{CONTENTS}

1.0 intRODUCTION ........................ . . . . . . . .

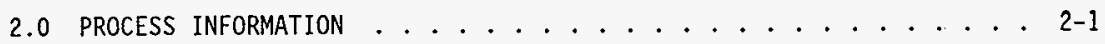

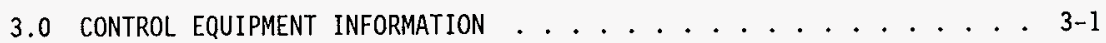

4.0 STACK INFORMATION ..................... 4- . .

5.0 PROCESS FLOW INFORMATION ................ 5-1

5.1 EXHAUSTER DESIGN .................... . . . . . . . . .

5.2 METHOD OF OPERATION ..........................

6.0 TOXIC AIR POLLUTANT EMISSIONS ESTIMATION .......... 6-1

6.1 EMISSIONS CALCULATIONS ............... . . . . . . .

6.2 SPECIFIC TAP CALCULATIONS ............. . . 6-1

7.0 SUMMARY OF COMPLIANCE WITH REQUIREMENTS .......... . . . .

8.0 REFERENCES ................... 8-1

\section{APPENDICES}

A BEST AVAILABLE CONTROL TECHNOLOGY FOR TOXICS ASSESSMENT ... APP A-i

B TOTAL ORGANIC CARBON AND AMMONIA MONITORING REQUIREMENTS FOR THE ROTARY MODE CORE SAMPLING SYSTEM .......... APP B-i

C UNIT CONCENTRATION FACTORS FROM ISC3 .......... APP C-i

\section{FIGURES}

1. Typical Components of the Rotary Mode Core Sampling System. . . . . . 1-2

2. Design Drawing of Exhaust System ............ . 4-2 
HEPA

HNF

LMHC

NOC

PNNL

RMCS

SST

SQER

T-BACT

TAP

TOC

Tri-Party Agreement

VOC

WAC

\section{TERMS}

acceptable source impact level

Defense Nuclear Facilities Safety Board double-shell tank

Washington State Department of Ecology

high-efficiency particulate air

Hanford Nuclear Facility (document identifier)

Lockheed Martin Hanford Corporation

notice of construction

Pacific Northwest Nationa] Laboratory

rotary mode core sampling

single-she 11 tank

small quantity emission rate

best available control technology for toxics

toxic air pollutant

total organic carbon

Hanford Federal Facility Agreement and Consent Order

volatile organic compounds

Washington Administrative Code 


\section{TOXIC AIR POLLUTANTS NOTICE OF CONSTRUCTION FOR ROTARY MODE CORE SAMPLING SYSTEMS THREE AND FOUR AND MODIFICATION OF SYSTEM TWO}

\subsection{INTRODUCTION}

The Washington State Department of Ecology (Ecology) approved the construction and operation of Rotary Mode Core Sampling (RMCS) System Two on November 22, 1993 (NOC-93-04). This approval supported the characterization of waste in the single-shell tanks (SSTs) and double-shell tanks (DSTs) on the Hanford Site. The waste tank characterization sampling and analysis effort is vital to the safe operations of the Hanford Site tank farms, and the timely collection of the information necessary to support retrieval, pretreatment, disposal planning, and final closure strategy.

Based on the Defense Nuclear Facilities Safety Board (DNFSB) Recommendation 93-05 Implementation P7an (DOE-RL-94-001), U.S. Department of Energy, Richland Operations Office (DOE-RL) proposed the expedited construction and operation of two additional RMCS systems to support characterization of waste stored in SSTs and DSTs. RMCS currently is scheduled for approximately 50 (active or passively ventilated) of the 149 SSTs in the 200 East and 200 West Areas. If necessary, the RMCS will be used to sample other tanks currently not scheduled, subject to the requirements of this document and any applicable Ecology approval order. The typical components of the RMCS systems are shown in Figure 1 . It should be noted that the Flammable Gas Detector cart (Figure 1) is not being used during RMCS at this time.

RMCS is scheduled for approximately 40 tanks that are not actively ventilated. These tanks operate at atmospheric pressure with passive (breather) high-efficiency particulate air (HEPA) filters. The RMCS system uses nitrogen gas to cool and purge the drill bit assembly. Without the use of a portable ventilation system, the additional gas from RMCS might unsafely pressurize tanks that are not actively ventilated. The RMCS system also will generate aerosols and dust in the tank vapor head space. HEPA filters will be required on the portable exhauster during rotary mode core drilling to control radionuclide particulate emissions. 


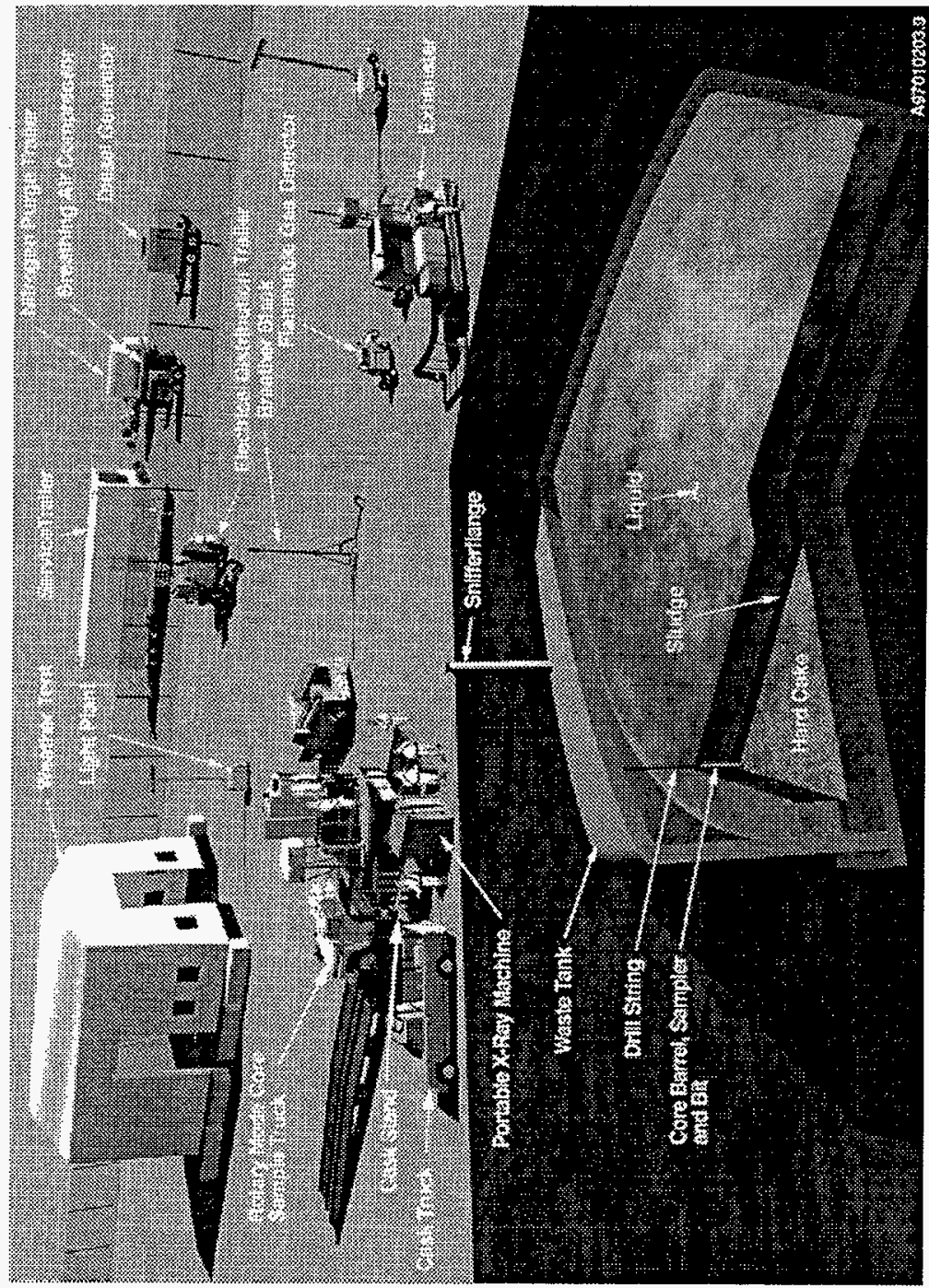

Figure 1. Typical Components of the Rotary Mode Core Sampling System. 


\subsection{PROCESS INFORMATION}

The RMCS system was designed to sample tanks containing hardened wastes. A prominent feature of this sampling system is the use of nitrogen gas to cool and purge the drill bit assembly. The purge will also allow a more complete sample recovery by clearing cuttings that might otherwise obstruct the sampler drill bit, and prevents cross contamination of different waste layers in the tank. The preferred mode of sampling is push-mode, which does not involve rotation of the drill string or significant purge gas flow. When the waste is too hard to push through, the core sample truck is placed in rotary mode to allow the bit to drill through the waste. It is during the rotary mode operation that an exhauster system is necessary.

of the approximately 50 tanks scheduled for RMCS, 40 tanks are not actively ventilated and operate at atmospheric pressure with passive HEPA filters. A portable HEPA filtered exhauster will be employed during RMCS in tanks that are not actively ventilated to prevent potentially unsafe tank pressurization and to control potentially radioactive aerosols and dust generated by RMCS. The portable exhauster must al so be moved between tank farms as needed with the RMCS system. Each exhauster may emit Toxic Air Pollutants (TAPs) subject to WAC 173-460. 
D0E/RL-94-117, Rev. 1

This page intentionally left blank. 


\subsection{CONTROL EQUIPMENT INFORMATION}

Particulate emissions will be controlled with prefilters and HEPA filters, which are being installed primarily to control radionuclide pollutants. The HEPA filters are rated to remove 99.95 percent for particulates with a median diameter of 0.3 micrometer and larger. Efficiency testing will be performed annually in accordance with onsite procedures. A total abated particulate emission value of 9.6 grams per year $(0.02$ pound per year), or a maximum daily average of 0.06 gram per day $(1.4 \mathrm{E}-04$ pounds per day), was provided to Washington State Department of Health (pursuant to WAC 246-247-110) and, thus, will not be regulated by Ecology.

A discussion of the best available control technology for toxics (T-BACT) is included as Appendix $A$ of this document. The recommendation of the T-BACT assessment is that no controls for TAP compounds be installed. 
D0E/RL-94-117, Rev. 1

$07 / 98$

1

2

3

4
5

This page intentionally left blank. 


\subsection{STACK INFORMATION}

The RMCS systems will be portable systems operating in the 200 East and 200 West Areas of the Hanford Site. Each system (Figure 1) is comprised primarily of a RMCS truck, an optional exhauster platform (Figure 2), an optional less than 500-horsepower diesel powered electric generator (typicaliy 300 horsepower), and a pressurized nitrogen gas tank platform.

The portable exhaust stack will be approximately $4.3 \mathrm{~m}(14 \mathrm{ft})$ high, with an effective height of more than $4.6 \mathrm{~m}$ (15 ft), and have a $10-\mathrm{cm}(4-\mathrm{in}$.) diameter duct. The average stack temperatures will be approximately $27^{\circ} \mathrm{C}$ $\left(80^{\circ} \mathrm{F}\right)$ and the exhaust rate will be approximately $5.7 \pm 1.4 \mathrm{~m}^{3} / \mathrm{min}$ $\left(200 \pm 50 \mathrm{ft}^{3} / \mathrm{min}\right)$. 


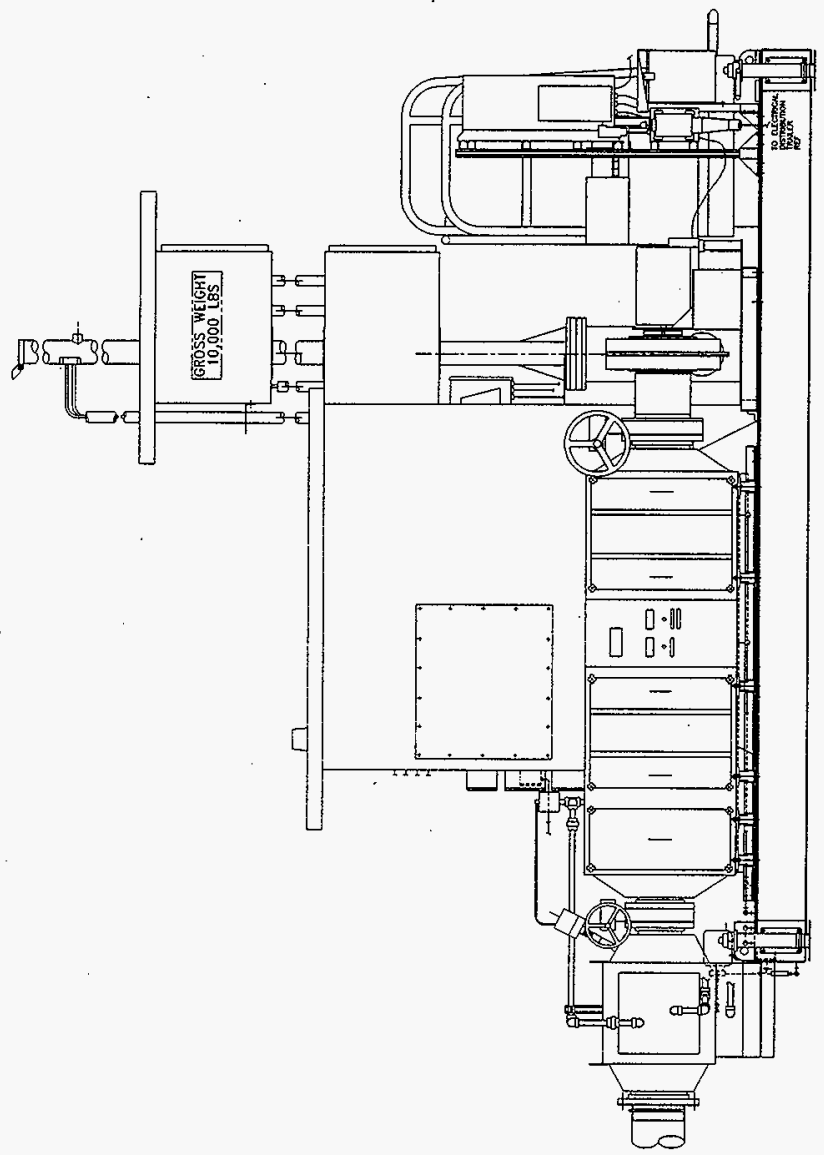

Figure 2. Design Drawing of Exhaust System. 


\subsection{PROCESS FLOW INFORMATION}

\subsection{EXHAUSTER DESIGN}

The exhauster system (i.e., control equipment, fan, and stack) design is shown in Figure 2. The exhauster is attached to a tank riser by a flexible connector. A prefilter is located in the filter housing immediately upstream of two HEPA filters in series. These HEPA filters are designed to remove particulate radionuclides. After passing through the HEPA filters, the exhaust gas is released to the atmosphere through the stack. The stack will contain an access port for monitoring both total organic carbon (TOC) and ammonia.

Operation of an exhauster is required to maintain a negative tank pressure with respect to the atmosphere during RMCS and to prevent uncontrolled radionuclide particulate emissions. With the addition of nitrogen and in-leakage to the tank, flow through the exhauster is designed for control at $5.7 \mathrm{~m}^{3} / \mathrm{min}\left(200 \mathrm{ft}^{3} / \mathrm{min}\right)$. At $5.7 \mathrm{~m}^{3} / \mathrm{min}\left(200 \mathrm{ft}^{3} / \mathrm{min}\right)$ tank pressure is about $-250 \mathrm{~Pa}$ or -1 in. water gauge (w.g.). Loss of the required exhauster will result in the automatic shutdown of the drilling process.

\subsection{METHOD OF OPERATION}

\section{[This paragraph moved to section 6.1]}

Whenever the dri11 bit is rotating, nitrogen gas wiil be injected into the drill string at approximately $0.85 \mathrm{~m}^{3} / \mathrm{min}\left(30 \mathrm{ft}^{3} / \mathrm{min}\right)$ to a maximum of $2.8 \mathrm{~m}^{3} / \mathrm{min}\left(100 \mathrm{ft}^{3} / \mathrm{min}\right)$. Each $48.3-\mathrm{cm}$ (19-in.) segment requires 5 to 20 minutes of drilling. While the sampler is being changed out after each segment, nitrogen will be injected into the drill string at approximately $0.03 \mathrm{~m}^{3} / \mathrm{min}\left(1 \mathrm{ft}^{3} / \mathrm{min}\right)$. This will maintain the hydrostatic head in the drill string (preventing waste from entering the space just sampled) and will allow for pressurization and depressurization of the sample receiver as necessary for sampler changeout.

Once a complete core has been obtained, the RMCS truck may either be repositioned on the same riser or moved to a different riser on the same tank to obtain a second core. When tank sampling is complete, the RMcS system will be disconnected and moved to the next tank. During system connection and disconnection, as-7ow-as-reasonably-achievable (ALARA) principles will be followed. 
This page intentionally left blank. 


\subsection{TOXIC AIR POLLUTANT EMISSIONS ESTIMATION}

In general, gas and vapor emissions from the exhauster can be estimated from quiescent waste tank headspace characterization data, headspace volumes, and exhauster flow rates. Current knowledge of the tank headspace gases and vapors, and the fact that tank headspace volumes are large compared to the specified exhauster flow rates, suggest TAP emission rates will be relatively low.

\subsection{EMISSIONS CALCULATIONS}

Before connecting the RMCS system to any tank, an air emissions estimate will be calculated, as described in Appendix B, using the existing tank vapor space data. If the calculated emission rate for any TAP exceeds its SQER, the actual RMCS exhauster operating time will be limited to maintain TAP emissions below the SQER. If the calculated emission rate for any TAP exceeds 50 percent of the established SQER, effluent monitoring will be performed as described in Appendix B.

The existing tank characterization vapor space data indicate some waste tanks contain chemical compounds that do not have WAC 173-460 SQER values. The TWINS database currently contains approximately 125 chemical compounds and classes of compounds identified in tank waste, of which six compounds do not have SQER values. A method to demonstrate compliance and/or monitoring requirements for each of these individual compounds is addressed in Section 6.2.

General1y, compounds with no.SQERs will be modeled for atmospheric dispersion, as allowed by WAC 173-460-080, using an EPA code (EPA-454-B-95-003a) and specific Hanford Site meteorological data to calculate the site boundary concentrations. The dispersion analyses will be performed in accordance with Appendix $C$. The worst-case concentration at any Hanford site boundary will be compared to the acceptable source impact level (ASIL) for the contaminant as listed in WAC 173-460. A Hanford Site boundary concentration less than the ASIL renders the tank acceptable for RMCS.

\subsection{SPECIFIC TAP CALCULATIONS}

Propionaldehyde and acetophenone, both Class B TAPs as listed in WAC 173-460-160, do not have an assigned ASIL or SQER values. A conservative assumption of assigning the smallest SQER for a ClasS B TAP $(0.02$ pound per hour) will be used in Appendix B calculations to provide an acceptable level of public health protection.

The Class A compound $\mathrm{N}$-nitrosodimethylamine does not have an SQER value but does have a WAC 173-460-150 ASIL value assigned. This compound will be modeled for dispersion and compared to the ASIL value.

The Class A compound 1,2 dichloropropane does not have an SQER but does 
1 will be modeled for dispersion and compared to the 24-hour average ASIL value specified in WAC $173-460$.

N-nitrosomorpholine does not have an SQER or ASIL value. To evaluate the risk of exposing the public to an unacceptable dose of this Class A TAP, a study was performed by Pacific Northwest National Laboratory (PNNL 1996) to identify a compound with similar toxicological characteristics to $\mathbb{N}$-nitrosomorpholine. PNNL identified 1-nitrosopyrrolidine as the chemical toxicity surrogate for $\mathrm{N}$-nitrosomorphol ine. The calculated ASIL for $\mathrm{N}$-nitrosomorpholine using 1-nitrosopyrrolidine as a surrogate is 1.63 E-03 micrograms per cubic meter. This ASIL will be used for comparison of offsite concentrations in the event a tank containing this compound requires RMCS.

The Class A TAPs, dioxins and furans (considered together as one TAP by WAC 173-460-050), do not have an SQER value but do have an ASIL. In accordance with WAC 173-460-050, dioxin and furan emissions are combined and considered as one TAP conservatively expressed as an equivalent emission of $2,3,7,8$ tetrachlorodibenzo-p-dioxin (TCDD). This TCDD compound is highly chlorinated, extremely carcinogenic, and has been assigned the smallest ASIL value of any compound 1isted in WAC 173-460.

With respect to the waste tanks, no dioxins have been detected and the furans detected in the tanks consist of 35 species of nonchlorinated furans (PNNL 1996). Given this information, the use of TCDD for Hanford tank nonchlorinated furans in the waste tanks is inappropriate. To evaluate the risk of exposing the public to an unacceptable dose of the nonchlorinated furans, a study was performed to identify a compound with toxicological characteristics believed to be representative of nonchlorinated furans. The study identified 1,4-Dioxane as the surrogate (PNNL 1998). The 1,4-dioxane ASIL will be used for comparison of offsite concentrations in the event a tank containing nonchlorinated furans requires RMCS.

The emissions resulting from the operation of the RMCS system are in compliance with the required standards of WAC-173-460. Compliance will be demonstrated by estimating emissions per Appendix B methodology, and limiting exhauster operation time such that actual emissions are less than the SQERs for those TAPs that have SQERs and less than the substitute SQERs or substitute ASILs for the specific TAPs described in this section. Stack emissions monitoring will be performed only for those tanks that meet Appendix B monitoring criteria. 


\subsection{SUMMARY OF COMPLIANCE WITH REQUIREMENTS}

Appendix A includes a T-BACT assessment, which recommends no controls for organic or inorganic vapors. The emissions resulting from the operation of the RMCS system are in compliance with the required standards of WAC-173-460. Compliance will be demonstrated by estimating emissions per Appendix B methodology, and limiting exhauster operation time such that actual emissions are less than the SQERs for those TAPs that have SQERs and less than the substitute SQERs or substitute ASILs for the specific TAPS described in Section 6.2. Stack emissions monitoring will be performed only for those tanks that meet Appendix B monitoring criteria.

13

14 
DOE/RL-94-117, Rev. 1 $07 / 98$

This page intentionally left blank. 
DOE/RL-94-117, Rev. 1 $07 / 98$

\subsection{REFERENCES}

D0E/RL-95-62, Nonradioactive Air Emissions Notice of Construction, Project $W-320,241-C-106$ Tank Sluicing, U.S. Department of Energy, Richland Operations office, Richland, Washington.

DOE/RL 94-0001, Recommendation 93-05 Implementation P7an, U.S. Department of Energy, Richland, Washington.

D0E/RL-93-41, Toxic Air Pol7utants Notice of Construction, Rotary Mode Core Sampling Truck and Exhauster, U.S. Department of Energy, Richland, Washington.

Ecology, 1995, Notice of Construction (NOC) Permit for the Construction of Two Rotary Mode Core Sampling Systems and the Modification of the Existing System, ORDER NO. NWP 95-RMCS(3), letter to U.S. Department of Energy, Richland Operations Office (June 30), Washington State Department of Ecology, Olympia, Washington.

Ecology, EPA, and DOE, 1996, Hanford Federal Facility Agreement and Consent Order, as amended, State of Washington Department of Ecology, U.S. Environmental Protection Agency, and U.S. Department of Energy, Richland, Washington.

EPA-454/B-95-003a, Industrial Source Complex Dispersion Model, screening procedures for estimating the air quality impact for stationary sources, updated periodically, U.S. Environmental Protection Agency, Research Triangle Park, North Carolina.

HNF-SD-WM-TSR-006, Tank Waste Remediation System Technical Safety Requirements, Fluor Daniel Hanford Company, Richland Washington.

NOC-93-04, Compliance With Condition 3, Approval of the Notice of Construction Application for Nonradioactive Emissions, letter to State of Washington Department of Ecology (February 18), U.S. Department of Energy, Richland, Operations office.

PNNL, 1996, Letter report to C. Grando (WHC) from D. Maughan (PNNL), Chemical Toxicity of N-Nitrosomorpholine (59-89-2), dated August 23, 1996.

PNNL, 1998, Letter report to D. Shuford (LMHC) from D. Maughan (PNNL), A Status Report on the Cancer Potential of Furan Chemicals in the Hanford Tank Headspace Gases and a Recommended Surrogate and ASIL for use in Assessing Chronic Public Exposure, dated March 12, 1998. 
D0E/RL-94-117, Rev. 1

$07 / 98$

This page intentionally left blank. 
DOE/RL-94-117, Rev. 1

$07 / 98$

4

\section{APPENDIX A} \\ BEST AVAILABLE CONTROL \\ TECHNOLOGY FOR TOXICS ASSESSMENT
}


DOE/RL-94-117, Rev. 1

$07 / 98$

This page intentionally left blank. 


\section{APPENDIX A \\ BEST AVAILABLE CONTROL TECHNOLOGY FOR TOXICS ASSESSMENT}

\section{A1.0 INTRODUCTION}

This appendix provides the basis for the management of toxic air pollutants resulting from rotary mode core sampling (RMCS) activities. The information is intended to demonstrate that the control equipment selected for the exhauster for the RMCS system complies with the requirements concerning the Best Available Control Technology for Toxics (T-BACT) as defined in the Washington Administrative Code (WAC) Chapter 173-460. The conclusions reached in this document are based on an evaluation of control technologies following the procedure described by the U.S. Environmental Protection Agency (in their draft policy document) ${ }^{1}$ and Ecology in an implementation resource manual. ${ }^{2}$

A description of the RMCS system, including the purpose for the system, is included in the Notice of Construction (NOC), to which this document has been appended. Please refer to the NOC for any information not directly related to the control of toxics.

\section{A2.0 UNABATED EMISSIONS}

Before connecting the RMCS system to a tank, the vapor space will be sampled and analyzed for TAPS. As discussed in Section 6.0 of this NOC, a calculation for all TAPs 1 isted in the TWINS data base for each tank will be performed as described in Appendix $B$ before RMCS.

\section{A3.0 TOP DOWN PROCEDURE}

There are five basic steps to determine T-BACT for a source. The first step is to identify all available control options. The second step is to eliminate options that are technically not feasible. The third step is to rank the remaining control technologies in order of control effectiveness. The fourth step is to evaluate the most effective controls considering energy, environmental, and economic impacts. If the top candidate is shown to be technically or economically not feasible, the next most stringent alternative

1 Prevention of Significant Deterioration and Nonattainment Area Permitting 47 (Draft), U.S. Environmental Protection Agency, Washington, D.C., 1990.

${ }^{2}$ Regulating Toxics, Implementation Resource Manual, State of Washington 49 Department of Ecology, 01ympia, Washington, 1991. 
1 is evaluated. Finally, a T-BACT selection is made when the most effective

2 control option cannot be el iminated because of energy, environmental, or

3 economic impacts.

\section{A4.0 CONTROL TECHNOLOGIES AVAILABLE}

Several technologies are available for the control of the contaminants included in the unabated emissions estimate. It should be noted that the exhauster will be equipped with a HEPA filter, regardless of the recommendation of this T-BACT analysis as a result of the requirements of WAC 246-247 and the U.S. Department of Energy.

Both organic and inorganic compounds are included in the unabated emissions estimate. The control technologies for each type of compound will be discussed separately.

\section{A4.1 CONTROLS FOR VOLATILE ORGANIC COMPOUNDS}

This section describes the various technologies for the control of volatile organic compounds (VOC). The technical feasibility of each is discussed in this section, as well.

\section{A4.1.1 Adsorption}

This technology has been used widely to capture VOC from emission sources. The stream is passed through a fixed bed of granular activated carbon, and adsorbed onto the carbon, or another adsorbent, such as a resin. This eventually depletes the available sites for adsorption, and the adsorbent must be either regenerated or discarded. This option appears to be technically feasible and will be discussed further in Section A5.0.

\section{A4.1.2 Thermal Incineration}

In this technology, the air stream is heated to about 816 to $1,093^{\circ} \mathrm{C}$ $\left(1,500\right.$ to $\left.2,000^{\circ} \mathrm{F}\right)$ for about a 1 second residence time. This chemically oxidizes the VOCs. Due to the relatively low heat content of the air stream, and the variability from tank to tank in vapor space composition, large quantities of fuel would be required for incineration, adding another large component (the fuel tank) to the RMCS system. Because of the potential presence of hydrogen in the vapor space of some of the tanks to be rotary mode core sampled this technology would not be considered inherently safe. Additionally, any system which would remove the incineration source from the proximity of the tank to minimize safety concerns would not be feasible, because the exhaust system cannot be outside of the fence line of the tank farm being exhausted. Consequently, installation is not technically feasible on any Hanford Site waste storage tank. 


\section{A4.1.3 Catalytic Incineration}

Catalytic incineration operates in the same manner as thermal incineration, with the exception that a catalyst is used in the reaction bed to reduce the temperature required to oxidize the vOCs. The presence of chlorinated compounds in the air stream will degrade the capability of the catalyst. Additionally, the temperatures required for this control technology are not sufficientiy low that the inherent safety of the system can be ascertained. Therefore, catalytic incineration is not technically feasible for this application.

\section{A4.1.4 Vapor Condensation}

This technology is used to recover and recycle volatilized solvents from industrial processes and in some cases has been used for VOC emission control, if the VOC concentration is extremely high. The air stream to be treated is cooled to below the dewpoint temperature of the VOC to be collected, and the condensed VOCs are decanted and recovered. This technology is not applicable to air streams with widely varying composition or concentration, because of the difficulties in designing the condenser for an uncertain process stream. Also, this technology is not well suited to air streams where the VOC concentration is less than the water vapor concentration, because the air coolers will become clogged with condensed ice. The tanks to be exhausted with this system are of highly varying composition, and some of the tanks are expected to have extremely high relative humidities. Therefore, this technology is not technically feasible.

\section{A4.2 CONTROLS FOR INORGANIC COMPOUNDS}

Only a limited quantity of methods have developed to control inorganic vapor emissions from point sources. The two most commonly used control methods are adsorption and absorption (or scrubbing).

\section{A4.2.1 Adsorption}

Adsorption of inorganic compounds is performed in the same way the adsorption of organic compounds is performed on granular activated carbon, however the adsorbent is different. For the control of ammonia (by far the inorganic compound of highest concentration in the vapor space), impregnated carbon has been shown to be an effective control device. This option appears to be technically feasible and will be discussed further in Section A5.0.

\section{A4.2.2 Absorption}

Absorption, or scrubbing, is used quite extensively in the control of inorganic compounds. In this technology, the air stream is contacted with a solvent, in which the inorganic compounds are highly soluble. The ideal solvent should be nonvolatile, noncorrosive, nonflammable, nontoxic, 
I chemically stable, readily available, and inexpensive. Water is the most commonly used solvent, and is used on a once-through basis. Unfortunately, there is no wastewater disposal system in the tank farms that can handle the quantity of wastewater that will be generated by this process. Additionaliy, there is a restriction on the water brought into the SST farms. This restriction does not allow water to be brought into a tank farm to be used as the solvent to scrub an air stream, nor does it allow water to be removed from tank farms for treatment elsewhere on site. Therefore, this technology is not technically feasible.

\section{A4.2.3 Incineration}

Thermal or catalytic incinerators can be used to control the emission of some inorganic compounds. However, a technically infeasible situation exists when applying these high temperature devices on tanks potentially containing concentrations of hydrogen in excess of the lower explosive level.

\section{A5.0 RANKING OF CONTROL TECHNOLOGIES}

Adsorption is the only technically feasible control technology available for organic or inorganic compounds. Therefore adsorption is ranked first, in order of effectiveness, and "no controls" is ranked second.

\section{A6.0 ENVIRONMENTAL, ECONOMIC, AND ENERGY IMPACTS}

The proposed RMCS System Three and Four were developed to be essentially identical to the approved System Two, with the primary goal of sampling the waste in the SSTs as efficiently, rapidly; and thoroughly as possible, while maintaining the integrity of the samples. Determining the contents of the tanks is the first step in retrieval, treatment, and eventual disposal of the wastes, which is required for clean-up of the Hanford Site.

At the flow rate selected for this exhauster, the technical feasibility of adsorption systems is questionable. EPA handbook $625 / 6-91 / 014^{3}$ does not recommend adsorption for flows less than $8.5 \mathrm{~m}^{3} / \mathrm{min}\left(300 \mathrm{ft}^{3} / \mathrm{min}\right)$ or temperatures greater than $54.4^{\circ} \mathrm{C}\left(130^{\circ} \mathrm{F}\right)$. To install these controls the flow rate would have to be increased and a chiller installed to ensure that the air stream was within the design parameters of the adsorption systems.

Additionally, the pressure drop through the controt technologies would cause the pressure in the tank to fall below acceptable safety criteria $(<-7.62 \mathrm{~cm} \mathrm{w.g.} \mathrm{[<-3} \mathrm{in.} \mathrm{w.g.]).} \mathrm{Addition} \mathrm{of} \mathrm{a} \mathrm{chiller} \mathrm{and} \mathrm{use} \mathrm{of} \mathrm{a} \mathrm{higher}$ flow rate are technically feasible and are required for adsorption to be

3 EPA, 1991, Contro7 Technologies for Hazardous Air Pollutants, EPA/625/691/014, U.S. Environmental Protection Agency, Washington, D.C. 
feasible. Consequently, the following discussion of impacts includes the use of a higher flow rate and chiller system.

\section{A6.1 ENVIRONMENTAL IMPACTS}

A system designed with the adsorption units would be extremely large, and would place the sampling of SSTs on a much slower track. Actual RMCS activities can take up to 21 days per tank. With the exhauster using VOC and ammonia adsorption, set-up and break-down could take up to another 21 days. Therefore, less than 9 tanks per unit could be sampled in a year. Delaying the schedule and increasing the time required to sample SSTs provides an environmental impact to the clean-up of the Hanford Site.

An adsorption system for the VOC was identified. This system used in-place regeneration with nitrogen and therefore did not have a significant secondary waste generation problems. However, there is an environmental impact in the generation of spent impregnated carbon from the ammonia adsorption system.

\section{A6.2 ECONOMIC IMPACTS}

An adsorption system on the exhauster would add $\$ 185,000$ to the operating cost to obtain one core sample. At a sampling rate of 30 cores per year (i.e., 15 tanks per year, 2 cores per tank), $\$ 5,550,000 /$ year, would be spent to include adsorption on the RMCS system (this does not include the capital cost of an adsorption system). At 99 percent efficiency, this unit could remove up to $34.2 \mathrm{~kg}$ (75.3 Tb) of TAPs per year (i.e., assuming the vapor space results from Tank 241-BY-110 are used to illustrate an annual average emissions rate). Therefore, the operating cost of the adsorption systems is $\$ 147 \mathrm{million} / \mathrm{ton}$ of TAPs (i.e, $\$ 162,000 / \mathrm{kg}[\$ 73,700 \mathrm{lb}]$ of TAPs).

Using a $300 \mathrm{hp}$ diesel engine to power the adsorption system at approximately $\$ 10 / \mathrm{h}, 24 \mathrm{~h} / \mathrm{day}, 14 \mathrm{~d} /$ tank, and 15 tanks/year, would cost more than $\$ 50,000 /$ year (see Section A6.3). The total economic impact of operating an adsorption system with the RMCS exhauster is more than $\$ 5.6$ million/year. Thus, the economic impact of the adsorption control technology is not efficient and does not justify its use.

\section{A6.3 ENERGY IMPACTS}

The operation of the previously designed system (including the VOC adsorber regeneration) required approximately $175 \mathrm{kVa}$ additional power. The power to the RMCS exhaust system is supplied by a diesel generator, and an additional diesel generator, of $300 \mathrm{hp}$ or less, would be required to supply power to the adsorption system. The economic impact of the additional energy requirements to support the adsorption technology, to remove less than $35 \mathrm{~kg}$ ( 76 lb) of toxics from the air stream, would cost more than $\$ 50,000 /$ year (i.e., more than $\$ 1,400 / \mathrm{kg}[\$ 669 / 1 \mathrm{~b}]$ ). Thus, the energy impact does not justify the added cost to control insignificant TAP emissions. 


\section{A7.0 CONCLUSION}

Based on the previous assessment, the unabated emissions, as a result of the planned activity do not represent significant emissions to the atmosphere. Exhauster operation time will be limited such that actual emissions are less than the SQERs for those TAPs that have SQERs and less than the substitute SQERs or substitute ASILs for the specific TAPs described in the text, Section 6.2. Additionally, the impacts of the control technology are not justified in the removal of an insignificant quantity of pollutants. Therefore, the T-BACT assessment recommends that no controls for TAPs be 15 
DOE/RL-94-117, Rev. 1

$07 / 98$

\section{APPENDIX B}

\section{TOTAL ORGANIC CARBON AND AMMONIA MONITORING REQUIREMENTS}

FOR THE ROTARY MODE CORE SAMPLING SYSTEM 
DOE/RL-94-117, Rev, 1

$07 / 98$

This page intentionally left blank. 


\section{APPENDIX B \\ TOTAL ORGANIC CARBON AND AMMONIA MONITORING REQUIREMENTS \\ FOR THE ROTARY MODE CORE SAMPLING SYSTEM}

\section{B1.0 INTRODUCTION}

A sample of the vapor space of each passively ventilated tank scheduled for rotary mode core sampling (RMCS) will be obtained as part of the preoperational steps. As discussed in the text, Section 6.0 , a calculation for all TAPs 1 isted in the TWINS database for each tank will be performed as described in this Appendix before RMCS. Results of this analysis will be used to determine the acceptability of performing RMCS on any given tank and the extra requirements and 1 imitations such as limiting exhauster operation or stack monitoring that might be imposed.

Figure BI represents the logic for determining the extra requirements such as monitoring or limiting the number of hours of exhauster operation to ensure emissions do not exceed the SQER. 


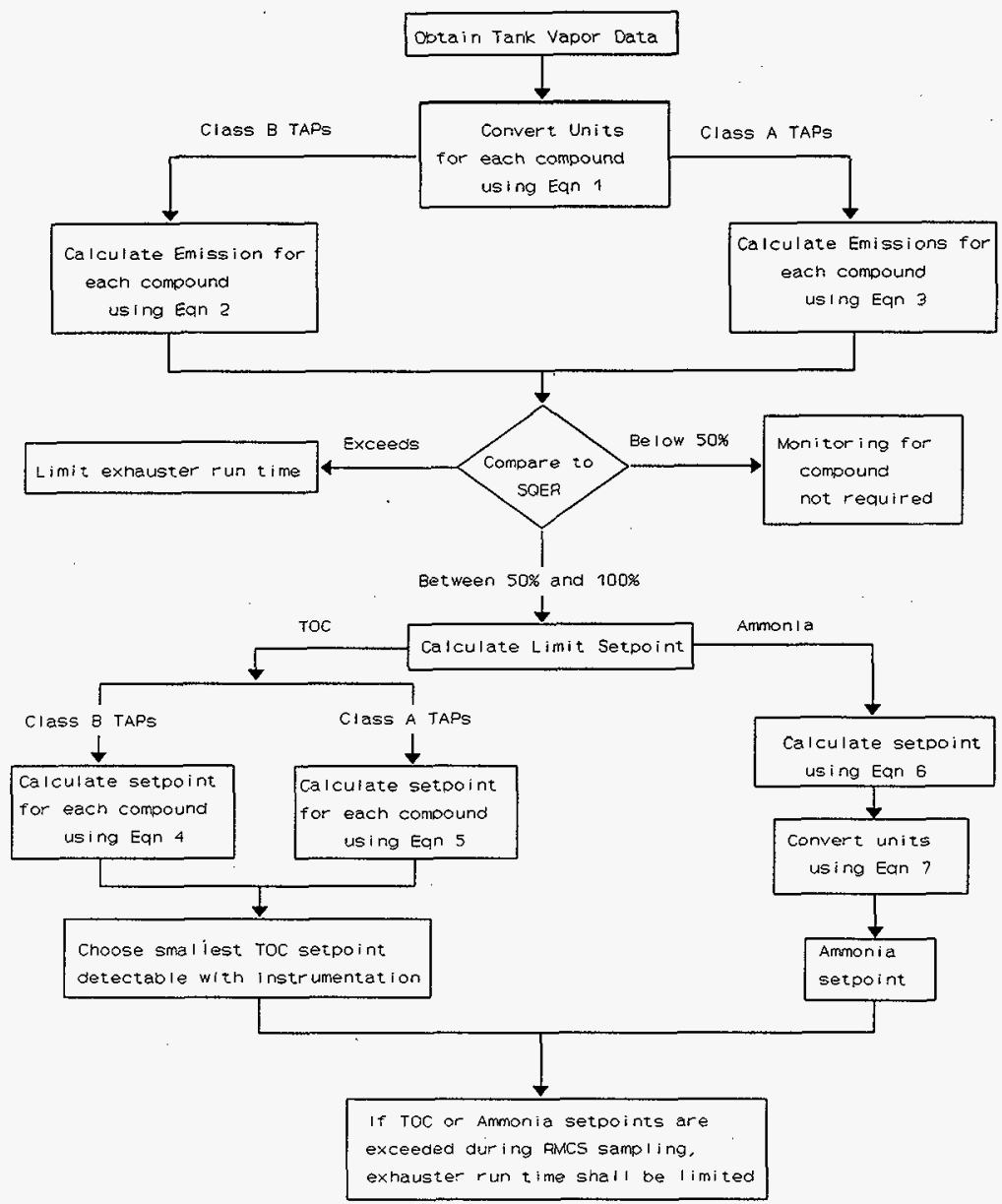

Figure B1. Total Organic Carbon and Ammonia Monitoring Requirements. 


\section{B2.0 DETERMINATION OF ACCEPTABILITY FOR ROTARY MODE CORE SAMPLING}

The following method will be used to determine whether a waste tank's vapor space is acceptable for RMCS:

- Convert ammonia and each organic species regulated as a class $A$ or class $B$ toxic air pollutant (TAP) from parts per million ( $P / M)$ by volume to milligrams per cubic meter using Equation 1:

$$
\frac{(\mathrm{p} / \mathrm{M})(\text { gram molecular weight })}{24.45}=\frac{\mathrm{mg}}{\mathrm{m}^{3}}
$$

- Convert ammonia and each organic species regulated as a class B TAP from milligrams per cubic meter to pounds per hour at $5.7 \mathrm{~m}^{3} / \mathrm{min}$ (200 $\left.\mathrm{ft}^{3} / \mathrm{min}\right)$ using Equation 2:

$$
\left[x \frac{\mathrm{mg}}{\mathrm{m}^{3}}\right]\left[\frac{339.8 \mathrm{~m}^{3}}{\mathrm{hr}}\right]\left[\frac{\mathrm{lb}}{453,593 \mathrm{mg}}\right]=X \frac{1 \mathrm{~b}}{\mathrm{hr}}
$$

- Convert each organic species regulated as a class A TAP from milligrams per cubic meter to pounds per year at $5.7 \mathrm{~m}^{3} / \mathrm{min}$ (200 $\left.\mathrm{ft}^{3} / \mathrm{min}\right)$ using Equation 3:

$$
\left(x \frac{\mathrm{mg}}{\mathrm{m}^{3}}\right)\left[\frac{339.8 \mathrm{~m}^{3}}{\mathrm{hr}}\right]\left[\frac{1344 \mathrm{hr}}{\mathrm{yr}}\right]\left[\frac{1 \mathrm{~b}}{453,593 \mathrm{mg}}\right]=X \frac{1 \mathrm{~b}}{\mathrm{yr}}
$$

where $\frac{672 \mathrm{hr}}{6 \mathrm{mo}}$ is the maximum operating time

in any tank as required by technical safety requirements (HNF-SD-WM-TSR-006).

If the calculated emission rate for any TAP exceeds its established SQER, the actual hours of RMCS exhauster operation will be reduced to maintain TAP emission estimates beiow permit limits. 


\section{B3.0 DETERMINATION OF MONITORING REQUIREMENTS}

If the calculated emission rate for any of the TAPs exceeds $50 \%$ of that TAP's established SQER, TOC monitoring is required during RMCS sampling. If ammonia exceeds 50 percent of its SQER, ammonia monitoring will be performed during RMCS sampling. Monitoring will be accomplished through the routine health and safety monitoring currently performed to ensure protection of personnel from TAP vapors. This approach to environmental compliance monitoring was approved by Ecology in DOE/RL-95-62.

If monitoring is the chosen option, the following criteria will be used to determine monitoring requirements:

- Establishment of a TOC 1 imit as described in Section B4.0 and/or establishment of an ammonia limit setpoint as described in Section B5.0.

- The frequency of TOC monitoring will be as follows:

- Once before starting the rotation of the drill string, with the exhauster operating

- Hourly during RMCS operations. 


\section{B4.0 DETERMINATION OF MONITORING REQUIREMENTS FOR TOTAL ORGANIC CARBON}

Assuming TOC monitoring is required, the following method will be used to determine a TOC limit setpoint:

- Determine a TOC 1 imit for each organic Class B TAP that exceeds 50 percent of its SQER and is fully detectable with the TOC monitor using equation 4:

$$
\frac{(\text { sample }[\text { TOC] })(\text { SQER of chemicaT X) }}{(\text { chemical } X \text { rate })}=\text { Limit [TOC] }
$$

where: $[T O C]=$ concentration of $T O C$ in $\mathrm{p} / \mathrm{M}$

SQER of chemical $X=$ SQER in $1 \mathrm{bs} / \mathrm{hr}$

chemical $X$ rate $=$ result of Equation 2 in $1 \mathrm{bs} / \mathrm{hr}$

13

14

15

16

- Determine a TOC Iimit for each organic Class A TAP that exceeds 50 percent of its SQER and is fully detectable with the TOC monitor using equation 5 :

$$
\frac{(\text { sample }[\text { TOC }])(\text { SQER of chemical } X)}{(\text { chemical } X \text { rate })}=\text { Limit [TOC] }
$$

Where: $[T O C]=$ concentration of $T O C$ in $\mathrm{p} / \mathrm{M}$ SQER of chemical $X=$ SQER in $1 \mathrm{bs} / \mathrm{yr}$ chemical $X$ rate = result of Equation 3 in $1 b s / y r$

Monitoring instrumentation must be capable of detecting TOC concentrations as determined by equations (4) and (5). Actual RMCS operational activities may be conducted above equations (4) and (5) concentrations as long as a safe shutdown of the RMCS equipment is initiated before emissions exceed the SQER. 


\section{B5.0 DETERMINATION OF MONITORING REQUIREMENTS FOR AMMONIA LIMIT SETPOINT}

Assuming ammonia monitoring is required, the following method will be used to determine an ammonia limit setpoint:

- Convert the SQER for ammonia to milligrams per cubic meter at $5.7 \mathrm{~m}^{3} / \mathrm{min}\left(200 \mathrm{ft}^{3} / \mathrm{min}\right)$ using equation 6 :

$$
\left(\operatorname{SQER} \frac{1 \mathrm{~b}}{\mathrm{hr}}\right]\left[\frac{\mathrm{hr}}{339.8 \mathrm{~m}^{3}}\right)\left[\frac{453,593 \mathrm{mg}}{1 \mathrm{~b}}\right]=X \frac{\mathrm{mg}}{\mathrm{m}^{3}}
$$

11

12

13

- Convert from milligrams per cubic meter to $\mathrm{p} / \mathrm{M}$ using equation 7 :

$$
\left[x \frac{m g}{m^{3}}\right]\left[\frac{24.45}{17.03}\right]=\text { Ammonia Limit }(p / M)
$$

14
Monitoring instrumentation must be capable of detecting ammonia concentrations determined by equations (6) and (7). Actual RMCS operationa] activities may be conducted above equation (6) and (7) concentrations as long as a safe shutdown of the RMCS equipment is initiated before emissions exceed the SQER. 


\section{APPENDIX C}

UNIT CONCENTRATION FACTORS FROM ISC3 
This page intentionally left blank. 
DON'T SAY IT -- Write It!

To: John S. Hill

H6-25 $\quad 372-1617$
Septenber 27. 1996

From: Paul D. Rittmann H0-31 $376-8715$

Subject: Unit Concentration Factors from ISC3

The ISC3 program (EPA-454/B-95-003a, "User's Guide for the Industrial Source Complex (ISC3) Dispersion Models". September 1995) was used to compute unit concentration factors for the Hanforo site boundary for 24 hour and annual releases from the $100-N$ (or $100-K$ ), the 200 West. the 200 East. and 300 Areas. Hanford site wind data is used for these calculations. The data for each area was collected in that area. For the 24 hour releases. hourly data from 1992. 1993. 1994. and 1995 was used. For the annual releases the joint frequency surmary for each area for the years 1986 to 1995 was used. Results are summarized in the first table below. These are the worst-case values for ground level releases from each area.

Table 1. Summary of Unit Concentration Factors for Ground Level Releases from Hanford Facilities

\begin{tabular}{|c|c|c|c|c|}
\hline \multirow[b]{2}{*}{$\begin{array}{l}\text { Release } \\
\text { Locations }\end{array}$} & \multicolumn{2}{|c|}{24 Hour Average } & \multicolumn{2}{|c|}{ Annual Average } \\
\hline & $\begin{array}{l}\text { Concen. } \\
\text { Factor }\end{array}$ & $\begin{array}{c}\text { Site Boundary } \\
\text { Location }\end{array}$ & $\begin{array}{l}\text { Concen. } \\
\text { Factor }\end{array}$ & $\begin{array}{c}\text { Site Boundary } \\
\text { Location }\end{array}$ \\
\hline $\begin{array}{l}100-N \& \text { KW } \\
200 \text { West Area } \\
200 \text { East Area } \\
300 \text {. Area }\end{array}$ & $\begin{array}{l}4.17 \\
3.46 \\
2.79 \\
38.1 \\
\end{array}$ & $\begin{array}{r}8.5 \mathrm{~km} W N W \\
12.6 \mathrm{~km} \mathrm{~S} \\
17.1 \mathrm{~km} E S E \\
1.1 \mathrm{~km} \quad \mathrm{E} \\
\end{array}$ & $\begin{array}{l}0.125 \\
0.0585 \\
0.0793 \\
1.56\end{array}$ & $\begin{array}{r}8.5 \mathrm{~km} \mathrm{WNW} \\
22.0 \mathrm{~km} \mathrm{SE} \\
17.1 \mathrm{~km} \text { ESE } \\
1.3 \mathrm{~km} \mathrm{NE} \\
\end{array}$ \\
\hline \multicolumn{5}{|c|}{$\begin{array}{l}\text { Note: Units for the Concentration Factors are } \mu 9 / \mathrm{m}^{3} \text { per } \mathrm{g} / \mathrm{s} \text {. } \\
\text { Peak values are given. } \\
\text { Note: Annual averages are based on Hanford Site wind data } \\
\text { collected over the years } 1986 \text { to } 1995 \text {. } \\
24 \text { hour averages are based on hour } 1 \mathrm{y} \text { Hanford Site wind data } \\
\text { for the years } 1992 \text {. 1993. 1994, and } 1995 \text {. }\end{array}$} \\
\hline
\end{tabular}

To use these factors, the rate at which a chemical is released into the air must be computed. To do this. the total amount (in grams) of the chemical released is divided by either 86,400 seconds ( 24 hours) or $31.557,600$ seconds ( 1 year). This release rate is then multiplied by one of the factors on Table 1 to compute the average concentration at the Hanford site boundary in $\mu \mathrm{g} / \mathrm{m}^{3}$. The formula below sumarizes the calculation.

$$
\text { Air Conc }\left(\mu \mathrm{g} / \mathrm{m}^{3}\right)=\frac{\text { (Total Release, grams }) *(\text { Concen. Föctor) }}{\text { Release Period. seconds }}
$$

As an example. suppose that 10 grams of amonia is released over a 24 hour period from the 200 West Area. Then the largest observed air concentiration at the Henford site boundary over the past four years is $0.0004 \mathrm{\mu g} / \mathrm{m}^{3}$ at a location $12.6 \mathrm{~km}$ south of the 200 West Area.

$$
\frac{(10 \mathrm{grams}) *\left(3.46 \mu \mathrm{g} / \mathrm{m}^{3} \mathrm{per} \mathrm{g} / \mathrm{s}\right)}{86.400 \mathrm{~seconds}}=4.0 \times 10^{-4} \mu \mathrm{g} / \mathrm{m}^{3}(12.6 \mathrm{~km} \mathrm{~S})
$$


Method of Calculatino the Concentration Factors

The first step was to estimate distances to the Hanford Site boundary from each of the areas of interest in all 16 wind transport directions. Table 2 shows the facilities selected and the distances obtained from the Hanford Map Distance (HMO) software by P.D. Rittmann.

Table 2. Distances (meters) to the Hanford Site Boundary

\begin{tabular}{|c|c|c|c|c|c|c|c|c|}
\hline \multirow{2}{*}{ Dir } & \multicolumn{2}{|c|}{$100-\mathrm{N}$ and $-K$} & \multicolumn{2}{c|}{200 West } & \multicolumn{2}{c|}{200 East } & \multicolumn{2}{|c|}{300 Area } \\
\cline { 2 - 8 } & $100 \mathrm{~N}$ & $100 \mathrm{KW}$ & CWC & RED0X & PUREX & WESF & 324 & 333 \\
\hline N & 9600 & 11000 & 17300 & 20300 & 24600 & 19400 & 7000 & 8700 \\
NNW & 8700 & 8900 & 15500 & 18100 & 21200 & 16700 & 46000 & 45500 \\
NW & 8300 & 8700 & 14600 & 17200 & 21300 & 18100 & 48600 & 48100 \\
WWW & 8500 & 10100 & 11800 & 13200 & 21200 & 19300 & 28500 & 28200 \\
W & 11500 & 12100 & 11500 & 13000 & 20700 & 18900 & 6000 & 6700 \\
WSW & 17300 & 15700 & 11800 & 13300 & 21100 & 19400 & 3500 & 4200 \\
SW & 20500 & 17400 & 13800 & 15500 & 17100 & 19900 & 2400 & 2900 \\
SSW & 28600 & 25600 & 15100 & 12800 & 16800 & 19600 & 2000 & 2700 \\
S & 28600 & 25200 & 14700 & 12600 & 19600 & 22800 & 1900 & 2400 \\
SSE & 34100 & 31000 & 19200 & 18200 & 19800 & 25500 & 1900 & 2400 \\
SE & 27300 & 32100 & 24700 & 22000 & 24300 & 19900 & 1500 & 1700 \\
ESE & 19100 & 21700 & 29900 & 28700 & 20200 & 17100 & 1200 & 1400 \\
E & 17300 & 20600 & 24300 & 25000 & 16000 & 16900 & 1100 & 1300 \\
ENE & 17300 & 20400 & 24600 & 23200 & 15300 & 21900 & 1100 & 1300 \\
NE & 16300 & 19900 & 27400 & 26400 & 18100 & 26400 & 1300 & 1500 \\
NNE & 13800 & 15200 & 25000 & 28800 & 23600 & 21100 & 1800 & 2200 \\
\hline
\end{tabular}

The second step was to obtain Hanford Site wind data from Kenneth W. Burk at PNNL. The wind data for each area is then used in the ISC3 calculations.

The third step is to create input files for the ISC3 software. Two of the input files are attached for reference. The first is an annual average calculation using ISCLT. while the second is a 24 hour calculation using ISCST. Both use a release height of 2 meters. with an exhaust flow rate of $2000 \mathrm{cfm}$ at a temperature of $20^{\circ} \mathrm{C}$. These conditions model ground Tevel releases.

The final step was to arrange the ISC3 results into Tables 3 and 4 . The worst case concentration factor was taken for each area. These worst-case results are listed in Table 1. 
Table 3. Annual Average Concentration Factors $\left(\mu \mathrm{g} / \mathrm{m}^{3}\right.$ per $\mathrm{g} / \mathrm{s}$ ) from Ground Level Releases

\begin{tabular}{|c|c|c|c|c|c|c|c|c|}
\hline \multirow{2}{*}{ Dir } & \multicolumn{2}{|c|}{$100-\mathrm{N}$ and $-\mathrm{K}$} & \multicolumn{2}{c|}{200 West } & \multicolumn{2}{|c|}{200 East } & \multicolumn{2}{|c|}{300 Area } \\
\cline { 2 - 9 } & $100 \mathrm{~N}$ & $100 \mathrm{KW}$ & CWC & REDOX & PUREX & WESF & 324 & 333 \\
\hline N & 0.0500 & 0.0410 & 0.0249 & 0.0200 & 0.0136 & 0.0187 & 0.145 & 0.106 \\
NWW & 0.0656 & 0.0635 & 0.0311 & 0.0251 & 0.0216 & 0.0300 & 0.011 & 0.012 \\
NW & 0.1064 & 0.0993 & 0.0381 & 0.0303 & 0.0220 & 0.0276 & 0.014 & 0.014 \\
WWW & 0.1252 & 0.0973 & 0.0351 & 0.0299 & 0.0173 & 0.0197 & 0.017 & 0.017 \\
$W$ & 0.0863 & 0.0803 & 0.0290 & 0.0243 & 0.0150 & 0.0171 & 0.059 & 0.050 \\
WSW & 0.0373 & 0.0427 & 0.0233 & 0.0196 & 0.0112 & 0.0126 & 0.079 & 0.060 \\
SW & 0.0234 & 0.0293 & 0.0212 & 0.0179 & 0.0154 & 0.0124 & 0.157 & 0.117 \\
SSW & 0.0126 & 0.0146 & 0.0246 & 0.0312 & 0.0153 & 0.0123 & 0.403 & 0.255 \\
S & 0.0136 & 0.0161 & 0.0366 & 0.0457 & 0.0147 & 0.0119 & 0.992 & 0.696 \\
SSE & 0.0131 & 0.0148 & 0.0368 & 0.0396 & 0.0189 & 0.0133 & 1.171 & 0.823 \\
SE & 0.0230 & 0.0186 & 0.0500 & 0.0585 & 0.0289 & 0.0380 & 1.248 & 1.036 \\
ESE & 0.0504 & 0.0423 & 0.0532 & 0.0562 & 0.0629 & 0.0793 & 1.142 & 0.917 \\
E & 0.0661 & 0.0520 & 0.0505 & 0.0486 & 0.0585 & 0.0542 & 1.184 & 0.933 \\
ENE & 0.0555 & 0.0442 & 0.0306 & 0.0331 & 0.0366 & 0.0224 & 1.382 & 1.082 \\
NE & 0.0389 & 0.0295 & 0.0182 & 0.0191 & 0.0207 & 0.0124 & 1.558 & 1.256 \\
NNEE & 0.0318 & 0.0277 & 0.0153 & 0.0127 & 0.0117 & 0.0136 & 0.975 & 0.719 \\
\hline
\end{tabular}

Table 4. 24 Hour Average Concentration Factors $\left(\mu \mathrm{g} / \mathrm{m}^{3}\right.$ per $\left.\mathrm{g} / \mathrm{s}\right)$ from Ground Level Releases

\begin{tabular}{|c|c|c|c|c|c|c|c|c|}
\hline \multirow{2}{*}{ Dir } & \multicolumn{2}{|c|}{$100-\mathrm{N}$ and $-\mathrm{K}$} & \multicolumn{2}{|c|}{200 West } & \multicolumn{2}{c|}{200 East } & \multicolumn{2}{c|}{300 Area } \\
\cline { 2 - 9 } & $100 \mathrm{~N}$ & $100 \mathrm{KW}$ & CWC & REDOX & PUREX & WESF & 324 & 333 \\
\hline N & 3.75 & 3.30 & 1.96 & 1.70 & 1.29 & 1.71 & 5.91 & 4.47 \\
NWW & 3.20 & 3.13 & 3.30 & 2.84 & 1.95 & 2.45 & 0.52 & 0.53 \\
NW & 2.29 & 2.17 & 0.78 & 0.64 & 0.53 & 0.62 & 0.29 & 0.30 \\
WNW & 4.17 & 3.51 & 2.16 & 1.94 & 1.16 & 1.28 & 1.12 & 1.13 \\
W & 2.51 & 2.35 & 3.24 & 2.91 & 1.74 & 1.89 & 4.25 & 3.66 \\
WSW & 1.42 & 1.57 & 1.90 & 1.69 & 0.29 & 0.32 & 6.05 & 5.08 \\
SW & 0.81 & 0.96 & 0.79 & 0.71 & 1.31 & 1.13 & 4.79 & 3.97 \\
SSW & 0.92 & 1.02 & 1.92 & 2.30 & 1.39 & 1.20 & 1.91 & 8.91 \\
S & 0.90 & 1.01 & 3.02 & 3.46 & 1.69 & 1.48 & 7.25 & 9.85 \\
SSE & 0.81 & 0.90 & 2.64 & 2.78 & 1.31 & 1.02 & 0.01 & 5.84 \\
SE & 0.51 & 0.41 & 0.99 & 1.12 & 1.00 & 1.29 & 6.44 & 3.08 \\
ESE & 1.62 & 1.44 & 2.51 & 2.61 & 2.36 & 2.79 & 8.42 & 4.65 \\
E & 3.23 & 2.76 & 2.44 & 2.38 & 1.73 & 1.64 & 8.11 & 0.78 \\
ENE & 2.71 & 2.30 & 1.69 & 1.78 & 1.10 & 0.73 & 7.63 & 2.98 \\
NE & 0.61 & 0.48 & 0.91 & 0.95 & 0.41 & 0.26 & 1.38 & 8.12 \\
NNE & 2.36 & 2.15 & 1.95 & 1.70 & 0.97 & 1.08 & 6.36 & 3.08 \\
\hline
\end{tabular}


ISCLT Input File for $100 \cdot \mathrm{N}$ Area

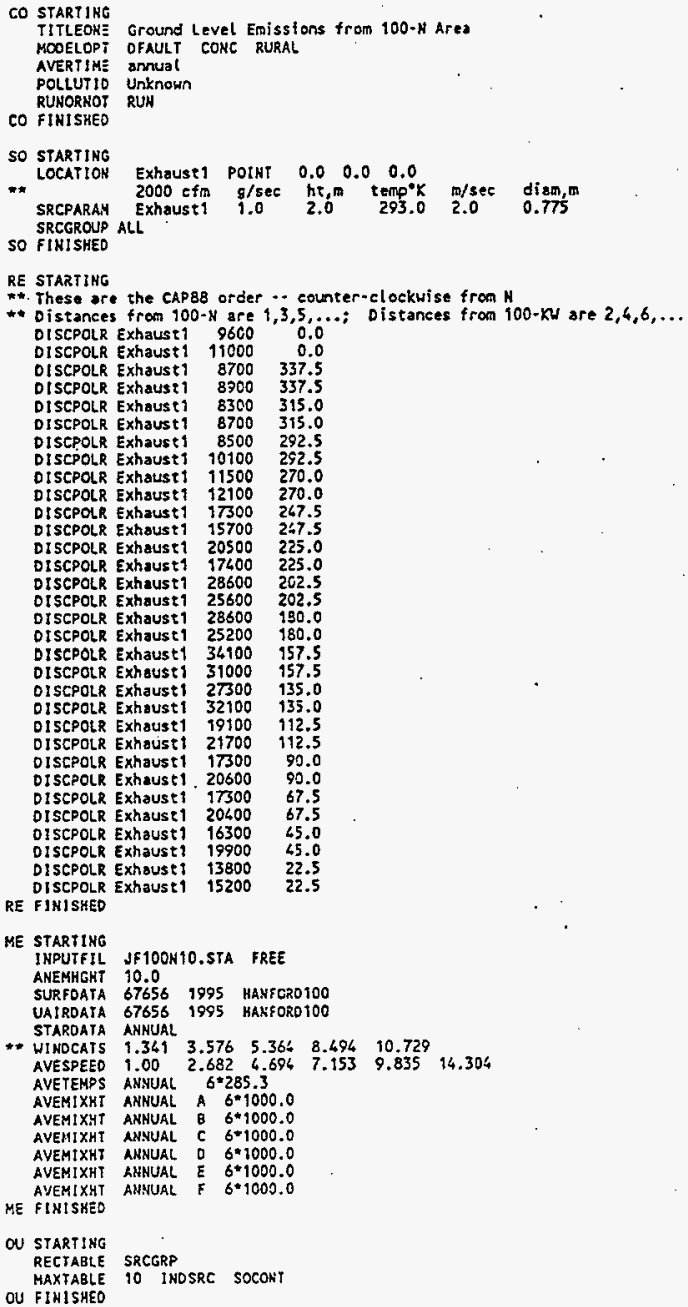


ISCST Input File for 200 West Area

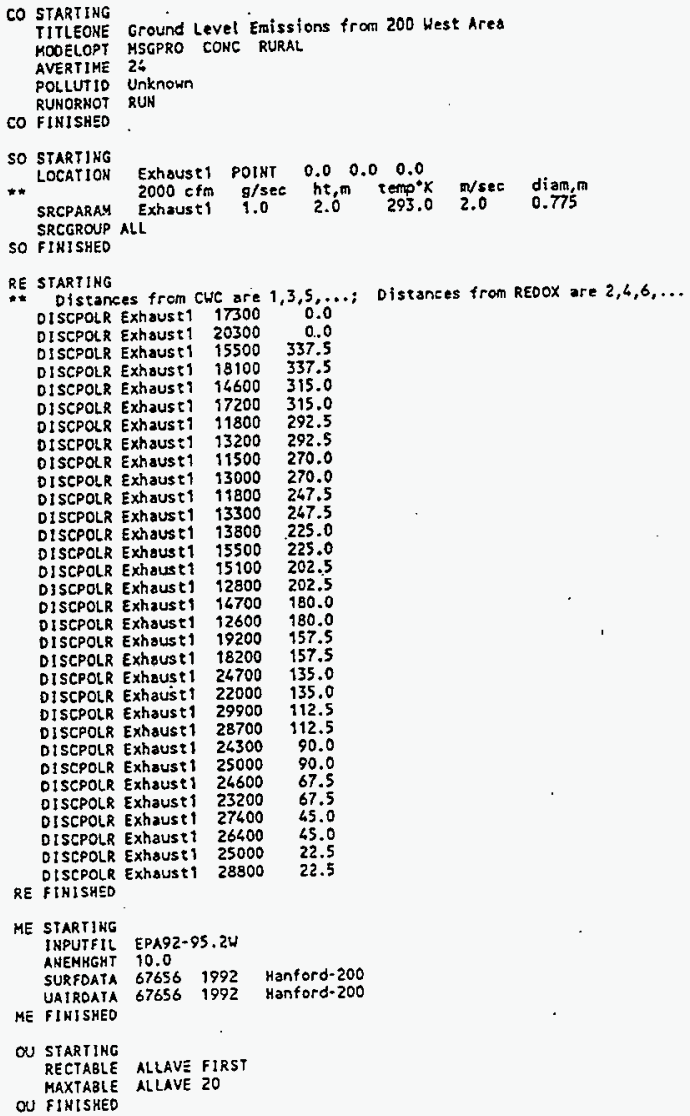


This page intentionally left blank. 


\section{DISTRIBUTION}

MSIN

J. L. Hensley

Washington State Department of Ecology

B5-18

M. A. Wilson

B5-18

Washington State Department of Ecology

Jerry Leitch, Chief

Radiation and Indoor Air Section

U.S. Environmental Protection Agency, Region 10

1200 Sixth Avenue

Seattle, Washington 98101

J. Wilkinson

Confederated Tribes of the Umatilla Indian Nation

P.0. Box 638

Pendleton, Oregon 97801

D. Powaukee

Nez Perce Tribe

P.0. Box 365

Lapwai, Idaho 93540

R. Jim, Manager

Environmental Restoration/Waste Management Program

Yakima Indian Nation

P.0. Box 151

Toppenish, Washington 98948

U.S. Department of Energy, Richland Operations Office

D. W. Bowser

A2-22

J. M. Clark

S7-54

C. C. Haass

S7-51

H. M. Rodriguez

A5- 15

Reading Room

$\mathrm{H} 2-53$

Pacific Northwest National Laboratory

Hanford Technical Library

$\mathrm{K} 1-11$

Fluor Daniel Hanford. Inc.

K. A. Petersen

H6-36

B. D. Williamson

83-15

Lockheed Mart in Hanford Corporation

M. L. Dexter

D. L. Dyekman

R1-51

P. C. Miller

D. H. Shuford 
Waste Management Federal Services of Hanford, Inc.

E. M. Greager

H6-21

N. A. Homan

H6-25

J. J. Luke

H6-25

Air Operating Permit File

H6-25

Lockheed Martin Services, Inc.

Central Files

DPC

B1-07

EDMC (2)

H6-08 